\title{
LOS SERMONES POLÍTICOS DE JOSÉ MARIANO BERISTÁIN DE SOUZA
}

A pesar de que sin duda Beristáin de Souza es uno de los personajes más interesantes de nuestro siglo XVIII novohispano, hasta ahora los investigadores se han sentido más inclinados a valorar su Biblioteca Hispanoamericana Septentrional (como lo prueba el excelente estudio de Agustín Millares Carlo*) sin acercarse a otros aspectos de su obra, también muy importantes, como son sus sermones. Beristáin de Souza, además de excelente bibliógrafo, fue también uno de los oradores sagrados más prolíficos de su época. Su influencia en el púlpito fue muy grande y sus "Oraciones" gozaban del beneplácito de un importante sector social en la Colonia y eran conocidas y celebradas por el sector realista pro-español.

$\mathrm{Su}$ olvido actual tiene varias causas. Por un lado, el estudio del género sermonístico en Nueva España parece a priori un campo poco atractivo. Por otro, sin duda es inseguro y arriesgado, ya que no existe ni siquiera una buena historia de la iglesia en México que pueda servir de referencia. Es indudable que los sermones ocupan una parte cuantitativamente muy importante de la producción literaria de Nueva España en los siglos XVI al XVIII. Por ello me voy a dedicar aquí a comentar algunos de los que Beristáin de Souza predicó durante la época pre-independentista en Nueva España desde 1794-1796; analizaré también los que predicó ya en pleno movimiento insurgente, desde 1810 hasta 1815. En todos ellos destaca una pasión pro-española que le impidió comprender la insurgencia y la modernidad que traía consigo el proyecto independentista de Hidalgo y sus seguidores, a quienes persiguió con su pluma con más vigor que otros con la espada.

* Agustín Millares Carlo, Don José Mariano Beristáin de Souza, Instituto Enrique Flórez, C.S.I.C., Madrid, 1975, pp. 53-54. 
Para Beristáin, como para otros muchos criollos, la conquista y la colonización fueron empresas civilizadoras y trajeron cultura y religión a un continente sumido en el paganismo y la crueldad, aunque no en la inopia cultural. Para el poblano, todo el acervo cultural prehispánico tendía a un extremo erróneo por el solo hecho de no estar enmarcado en la verdadera religión. Así, la conquista reencauzó esos conocimientos de los naturales, al dotarlos de un sentido cristiano, y los enriqueció con la avanzada cultura renacentista europea y española. Estas mismas ideas están plasmadas, a manera de diálogo humanista (lo que no es una casualidad), en una obrita suya muy poco estudiada y extremadamente interesante, los Diálogos patrióticos, publicada en la Imprenta de Jáuregui, México, en 1810.

En esta obra, al igual que en la "Disertación apologética" que sirve de prólogo a la Biblioteca Hispanoamericana, Beristáin expone sus ideas sobre la insurgencia. Para él, los rebeldes querían retroceder en el tiempo y arrebatar a las colonias logros y progresos, tanto culturales como económicos, que se habían conseguido bajo la tutela española y con la religión cristiana. Las tropas insurgentes no son sino una masa de hombres engañados y de perdidos miserables que quieren, a través de la ratería y el asesinato, volver a la época de los sacrificios humanos. La obra toda de Beristáin argumenta, con los papeles en la mano, a favor de la cultura española que se ha impuesto en Nueva España porque, según él mismo indica, su Biblioteca Hispanoamericana (y por extensión, el resto de su bibliografía)

basta para interesar en la lectura de la obra no solamente a los ingenios mexicanos, sino a todos los españoles y aun a los extranjeros. Porque a los primeros se les presenta la historia de su literatura y de sus sabios, a los segundos se les lisonjea con los frutos de su liberal e ilustrado gobierno en la América, y a los terceros se les abre un nuevo teatro de sorpresas, en que después de adorarse los tesoros preciosos que encierran las posesiones ultramarinas de la España, puedan hacer un sinnúmero de reflexiones, todas honoríficas a la generosa conquistadora del Nuevo Mundo ${ }^{1}$.

${ }^{1}$ El original de la Biblioteca Hispanoamericana se encuentra en la Biblioteca de Palacio (Madrid). ms. 1663-1665. 
Sobre esta característica sobresaliente que fundamenta la obra de Beristáin, citaré asimismo un fragmento de los Diálogos patrióticos en los que justifica su actitud. Los insurgentes, dice, mienten cuando afirman que la conquista y la Colonia sólo han traído desgracias a la Nueva España, acusando a la Madre Patria de depravaciones, corruptelas y explotación. Por fortuna - sigue Beristáin - no todos caen en esta tramposa argumentación de los rebeldes, pues "aún quedan en las Américas muchos millares de españoles fieles, nobles, sensatos, justos y agradecidos a su gran madre que, reconociendo lo que le deben y calculando mejor sus verdaderos intereses, lloran amargamente el descarrío de sus hermanos y la desolación de la patria, que es el fruto infernal que ha producido la insurrección"'?.

En otro lugar dice nuestro autor:

Mi Biblioteca no es "selecta" sino histórica y universal, y todo debe ponerse en ella, y así encierra mucho bueno, mucho malo, mucho mediano y bastante selecto y muy apreciable. Y [aun] cuando todo fuese mediano ¿qué resultaría? Que no podríamos sentarnos en el banco de arriba de la academia de los sabios europeos. Sea en buena hora. Pero desde estar sentados en el banco de abajo a estar (como se cree y se calumnia) con la cadena al cuello, vegetando no más y acaso pastando en los campos, hay una infinita distancia ${ }^{3}$.

\section{Los sermones de José Mariano Beristáin de Souza}

Hemos dicho ya que la política, la agitada política de los tiempos que vivió, fue el leitmotio de toda la obra del canónigo mexicano. Sus sermones no son una excepción.

La insurgencia motivó en la Colonia una avalancha de literatura de tipo político-religioso (cartas pastorales, edictos de excomunión, sermones, homilías) en las que se mezclaron como nunca antes los dos temas: el religioso y el político. Así lo entendió también Julio Zárate cuando escribió:

que las armas de la iglesia se esgrimieron más contra la rebelión que contra la supuesta herejía de los independientes lo prueban todos los

${ }^{2}$ Diálogos patrióticos, Impta. de Jáuregui, 1810, reimpreso en la Impta. de Benito Monfort, Valencia, 1811, p. xiii.

3 "Discurso apologético" que sirve como prólogo a Ia Biblioteca Hispanoamericana Septentrional, XVIII. 
documentos emanados de los obispos, los sermones predicados en los púlpitos, convertidos entonces en tribunas, y los procedimnientos de la Inquisición en daño de los principales caudillos. Quizás en ninguna época como ésa el trono y el altar se unieron más íntimamente, y nunca como entonces los santos preceptos del cristianismo, de paz, de amor, de caridad y de tolerancia fueron más olvidados y desconocidos por los mismos que tienen la misión de inculcarlos y defenderlos en la tierra. La ira se desborda en todos los edictos y pastorales de esos días y los dicterios quedan agotados en cada uno de los anatemas lanzados contra la revolución ${ }^{4}$.

Esta mezcla se dio también en el campo insurgente desde que Hidalgo enarboló como estandarte la imagen de la Virgen de Guadalupe. Ello llevó a los realistas a adoptar como patrona a la Virgen de los Remedios.

Ante la inminente entrada de las tropas alzadas en la capital de la colonia, la imagen de esta Virgen fue llevada procesionalmente desde su iglesia a la catedral, como cuando ocurrían las grandes catástrofes naturales. Se crearon batallones con su nombre y hasta las mujeres, instigadas por la viuda de un oidor del Ayuntamiento, se hicieron "Patriotas marianas". Las imágenes fueron investidas como "generalas" y se les dio bastón de mando y la banda correspondiente. A esta peregrina situación colaboró no poco nuestro Beristáin con sus inflamados sermones contra los insurgentes y contra Napoleón Bonaparte, quien a la sazón era visto por los realistas como el peor enemigo de las colonias españolas de América y como el verdadero instigador de la revuelta.

Cuando Hidalgo, por razones todavía no aclaradas, decidió posponer el ataque a la capital y retirarse de sus proximidades, los realistas justificaron esta decisión por la intervención de la Virgen de los Remedios, que según ellos había impedido que los "herejes" atacaran su plaza. Así, el pensamiento mágico-mítico formó parte integrante de la lucha ideológica que se estaba llevando a cabo en contra de la facción insurgente.

No todos los títulos de estos sermones dan idea de su contenido, pero éste podría resumirse con el de uno de ellos: "Discurso cristiano/declamatorio contra los rebeldes de la Nueva España”, (1816).

Al mismo tiempo que Beristáin predicaba contra los insurgentes, se ocupaba también de la edición de un periódico cuyo título

${ }^{4}$ Julio Zárate, La guerra de Independencia, en Vicente Riva Palacio et al., México a través de los siglos, vol. 5, Cumbre, México, 1978, p. 130. 
era El Verdadero Ilustrador Americano, en el que naturalmente defendía las tesis contrarias a las de El Ilustrador Americano surgido de las filas rebeldes, al cual Beristáin llamaba " $\mathrm{El}$ falso ilustrador". En el tercer número de El Verdadero Ilustrador. . . se resume el contenido de esta elocuente manera: "Continúase hablando con los españoles insurgentes y se añaden cuatro palabras a los españoles buenos: dos a los europeos y dos a los americanos". En el núm. 4, Beristáin escribe "Captada ya a mi parecer la benevolencia de muchos de mis lectores, y cuando menos la atención de otros y acaso la curiosidad nomás de algunos, comienzo a haberlas con el autor de papel infernal publicado en Sultepec con el título de Ilustrador Americano" 5 .

Beristáin tuvo también otras actividades en esta época. En 1812, varios españoles americanos (como él llamaba a los criollos), conspiraron para asesinar al virrey Venegas. Sin embargo, uno delató a sus compañeros, que en su mayoría fueron condenados a muerte. Beristáin, junto con otros miembros del cabildo de catedral, ofreció una misa de acción de gracias por haber sido descubierto el complot, y fue él mismo el encargado de pronunciar el sermón. El texto que dirigió al Virrey para anunciarle la celebración de la misa no puede ser más elocuente:

Muy Señor Nuestro: el Presidente y Cabildo de esta Santa Iglesia Metropolitana, reconocido al inestimable beneficio con que la infinita providencia de Dios ha salvado a todo el reyno frustrando los criminales designios de los monstruos que conspiraban contra la preciosa e importante vida del Exmo. Sr. Virrey, ha determinado celebrar una misa solemne en acción de gracias, mañana 10 del corriente.

Firman el escrito Juan de Mier y Villar (tío de fray Servando), Bartolomé Joaquín Sandoval, José Mariano Beristáin y Pedro Granados ${ }^{6}$.

Finalmente, podemos citar el edicto que como gobernador de la mitra en sede vacante publicó en 1815 :

${ }^{5}$ Las cursivas que se encuentran en todos los textos que cito son mías. El verdadero Ilustrador. . f fue publicado por la Impta. de Jáuregui. J. TORIBIO Medina, en La Imprenta en México lo cataloga en VIII, núm. 12153. Biblioteca Nacional de México, 11/LAF.

${ }^{6}$ Citado por Julio Zárate, op. cit., p. 256 y también por Millares GARLO, op. cit., pp. 69-70. 
Nos, el deán y cabildo de la Santa Iglesia Metropolitana, gobernador en sede vacante de este arzobispado. A todos los freles, estantes y habitantes de él de cualquiera estado, calidad y condición que sean, salud, gracia y paz en Nuestro Señor Jesucristo. Amén. SABED: que el desenfrenado hbertimaje de nuestros desleales y traidores hermanos los ha precipitado ya en el abismo a que ordinariamente conduce la corrupción de costumbres. No contentos con los innumerables males y desgracias que por su rebelión han acarreado a este antes feliz y bienaventurado reyno, se esfuerzan en desterrar de él la divina religión de nuestros padres con las perversas doctrinas que han vertido en sus detestables folletos y su escandaloso menosprecio de Jesuscrito y su Iglesia ${ }^{7}$.

\section{LA FELICIDAD DE LAS ARMAS DE ESFAÑA}

Ante la imposibilidad de abarcar aquí la ingente obra sermonística de Beristáin, me limitaré a tratar los sermones incluidos en la recopilación que él mismo hizo en 1815, La felicidad de las armas de España vinculada en la piedad de sus reyes, generales y soldados o el valor, la gloria, la virtud y la religión de los militares españoles demostradas en siete oraciones fúnebres que en sus solemnes exequias ha pronunciado ${ }^{8}$.

También tomaré en cuenta para mi exposición otros tres sermones sueltos: la "Oración panegírica-eucarística" incluida en el volumen Solemne acción de gracias que tributaron al Todopoderoso [...] los caballeros de la Real y distinguida orden española de Carlos III $(1809)^{9}$, el "Discurso político-moral y cristiano que en los solemnes cultos que rinde al Santísimo Sacramento en los días de Carnaval la Real Congregación de eclesiásticos oblatos...", $(1809)^{10}$, y el "Discurso para el Domingo de Ramos del año de 1815 ' contra los insurgentes $(1816)^{11}$.

7 "Edicto publicado por el gobernador de la mitra mexicana en sede vacante...", Archivo de Indias, Sevilla, Imp. 1488.

${ }^{8}$ Utilizo la edición hecha en la Imprenta de Jáuregui, México, 1815.

${ }^{9}$ En la Biblioteca Nacional de México se encuentra un ejemplar de esta Solemne acción de gracias..., en "Papeles referentes a la primera época de la In" dependencia", 643/LAF.

10 Biblioteca Nacional de México, 11/LAF.

${ }^{11} \mathrm{El}$ "Discurso para el Domingo de Ramos" fue publicado primero en la Impta. de Benavente (s.a. pero posiblemente 1815) y fue reimpreso al año siguiente en la de Álvarez, Madrid. Ejemplar de la primera edición en la Biblioteca Nacional de México, 171/LAF. 
La felicidad de las armas de España... consta de siete sermones breves (dado que en la catedral de México era preceptivo que los predicadores no extendieran su retórica por más de una hora), dedicados todos ellos al ejército español y predicados en el día del ejército en los años de 1794, 1798, 1800, 1803, 1805, 1810 y 1814. Todas las oraciones fueron pronunciadas en la catedral de México, excepto la última, que lo fue en Querétaro.

La primera y la última fueron dedicadas a dos hechos concretos: a los militares muertos en la guerra contra los franceses en el Rosellón, y a los sucesos del 2 de mayo madrileño contra el ejército napoleónico, respectivamente. Las otras forman un cuerpo aparte, ya que intentan hacer una historia de los soldados españoles a lo largo de la historia de España desde sus orígenes hasta la época de los Reyes Católicos. Sin embargo, en el fondo de los siete sermones de la recopilación y de los tres restantes late una misma idea unificadora: los mexicanos y los españoles deben fidelidad a Dios, al rey y a España.

Los enemigos a quienes van dirigidas todas las diatribas, tanto en el primer sermón de La felicidad. . . como en el último, " $\mathrm{La}$ triple fidelidad coronada", son Napoleón y su ejército francés, quienes atentan contra esta triple fidelidad; en el "Discurso político-moral" y en el del "Domingo de Ramos", los enemigos son los insurgentes que, influidos por los franceses, quieren romper la dependencia con España.

Al mismo tiempo, los beneficios que ha traído a la colonia la tutela española están reflejados en la "Oración panegíricoeucarística" y en el "Discurso político-moral y cristiano", aunque también trata este tema de los Diálogos patrióticos $(1811)^{12}$, en los que intenta demostrar también las herejías y las equivocaciones en que pensó que incurrían los insurgentes, asunto que fue para Beristáin una verdadera obsesión: "Entretanto, dejemos a los insurgentes que blasfemen y rabien cuanto quieran. No es nuevo en ellos el encono contra los hombres de bien, y particularmente contra el benemérito americano autor de la oración, porque con la palabra, con la pluma y con las obras ha sido siempre su principal y mayor enemigo" 13 .

12 El interés de los Diálogos es máximo para entender la ideología proespañolista en la Colonia. Se trata de un asunto tratado muy superficialmente por Joser MARÍA MiQuel y Vergés en La independencia mexicana y la prensa insurgente, Patria, México, 1941.

13 "Nota del editor mexicano" al Discurso para el Domingo de Ramos del año de 1815, Impta. de Benavente, México, s.a. (pero probablemente de 1815). 
Francia y Napoleón como enemigos: sermones I y VII de La felicidad de las armas de España

El Sermón I, "Elogio de los militares españoles difuntos en la guerra del Rosellón" (1794) $)^{14}$, tuvo dos ediciones: la primera en 1795, dedicada a Manuel Godoy, y la segunda, formando parte de la recopilación que nos ocupa. En la dedicatoria al valido de María Luisa, Beristáin lo llama "sabio ministro de estado, capitán general de los exércitos del rey, que desde su gabinete político infunde el valor a los tropas [...] tierno y amabilísimo patriota $[\ldots][y]$ español más fiel y religioso que jamás tuvo nuestro monarca al lado de su trono"' (p. 2).

Naturalmente, en la recopilación de 1815, esta dedicatoria desapareció, lo mismo que Godoy, que había pasado a ser un "maldito" de la política española.

Por lo demás, el sermón se publicó tal como había sido impreso en 1794.

El tema de la guerra contra la Francia revolucionaria después de la ejecución de Luis XVI fue tremendamente popular tanto en las colonias como en España. Se escribieron y editaron cientos de sermones, cartas pastorales y otros textos en los que se exaltaban los valores de las monarquías y la religión, dos temas que iban siempre unidos ${ }^{15}$.

En la larga lista de los que se ocuparon de la guerra de Francia contra España de 1793 podemos ver a Lorenzana en Toledo, a Armañá en Tarragona, a fray Diego de Cádiz, a fray Pedro Pont, a fray Antonio Díaz (predicador del rey al igual que el de Cádiz), y un largo etcétera ${ }^{16}$.

Beristáin, por su parte, interpretó todas las guerras españolas como guerras de religión o cruzadas espirituales; omitió en todo momento las circunstancias políticas, sociales o económicas que llevaron al pueblo a hacer la Revolución francesa o a la insur-

Este discurso fue reeditado bajo el título, más expresivo, de Discurso cristiano/ declamatorio contra los rebeldes de la Nueva España, en la Impta. de Álvarez, Madrid, 1816.

${ }^{14}$ La primera edición fue publicada por la Impta. de ia Viuda de Jáuregui en 1794, y no presenta con la segunda (la recopilación) sino las diferencias que señalo en el texto.

${ }^{15}$ Dedicatoria de la primera edición (1794) a Manuel Godoy, Príncipe de la Paz, 2a. hoja sin numerar.

${ }_{16}$ Richard HerR, The Eighteenth-century Revolution in Spain, Princeton University Press, Princeton, NJ, 1958, pp. 307 ss. 
gencia criolla, según el caso. Beristáin subordinó todo al factor religioso, que es el que le pareció dominante y sustantivo.

Francia, en este Sermón I, no sólo es una nación que atenta contra la soberanía del pueblo y del gobierno español, sino que es "un monstruo devorador de todo el linage humano, [un] dragón formidable que quiere tragarse la iglesia de Jesucristo y derribar de su solio al Omnipotente"' (I, p. 3).

Esta guerra santa se justifica a sí misma - opina Beristáinpues sus razones son humanitarias, religiosas y morales. Esta actitud de Beristáin y de una buena parte del clero español es un " síndrome de cruzada' que se ha repetido a lo largo de la historia española hasta llegar al siglo xx con Francisco Franco y su "cruzada" contra los "rojos".

En su análisis de los acontecimientos de 1793, Richard Herr nos dice: "With the language of the priests ringing in their ears, the Spanish people joined the war effort. For the masses of the nation, the Catholic religion was still their only guiding light, and to participate in a crusade for it as well as for their king and country was a universal duty' 17 .

Hemos de señalar que este sermón, predicado en la catedral de México, está en perfecto acuerdo con lo que en aquellos momentos se estaba predicando y publicando en otros puntos de América y España con el mismo motivo. La Revolución francesa sacudía efectivamente todos los cimientos de la nación española y sacaba a la luz toda una historia de resentimiento español contra la vecina Francia. Todos los estamentos de la sociedad, salvo contadas excepciones, contribuyeron en esta guerra que acabaría en derrota y en la llamada "Paz de Basilea", firmada entre Francia y España tres años después, y en la que la católica España tuvo que ceder la isla de Santo Domingo y comprometerse a una nueva alianza con su natural enemiga. Fue el preludio de la derrota de Trafalgar. Tanto pobres como ricos contribuyeron con dinero o con sus vidas a la lucha emprendida contra los franceses: "Those who could not afford money gave their personal possessions and clothing [...] lists of volunteers were nearly as common, especially at the beginning of the war'"18.

En el Sermón I, se califica a la contienda como justa y necesaria, pues

${ }_{17}$ Ibid., p. 312.

${ }^{18}$ Idem. 
se sostiene con vigor y decoro contra una nación corrompida, soberbia y sacrílega; contra un pueblo desenfrenado y orgulloso, que no contento con destruir el suave y dulcísimo yugo de la Casa de Borbón, a quien por espacio de dos siglos había idolatrado, y a cuyos príncipes debió su engrandecimiento, después de asesinar en un cadalso al más virtuoso y pacífico de sus monarcas, pensó, proyectó y trató de venir también a desatar las coyundas de seda y oro que nos unen y estrechan gustosamente, más que nos atan a los pies de un trono (I, pp. 6-7).

Creo que después de esta cita no es necesario señalar que la visión que ofrece Beristáin tanto de la Revolución francesa como del estado de la colonia respecto a España en 1793 es ahistórica y marcadamente tendenciosa. Se trata de una visión maniquea, en la que el enemigo es poseedor de todos los defectos y vilezas, mientras que España y su monarquía son dueños de todas las virtudes. Los púlpitos rebosaban predicadores que exponían con exaltación estas ideas.

Es indudable que mucha gente se dejó arrastrar por palabras similares en España, aunque Herr señala que a finales del mismo año de 1793, el entusiasmo popular había decrecido sensiblemente, sobre todo porque los esfuerzos enormes que se hacían no tenían relación con los resultados de la guerra.

En América, en cambio, muchos escucharon estos sermones con ironía o escepticismo, aunque las clases dominantes, los funcionarios y el clero estuvieron dispuestos a todo por mantener el prestigio de la monarquía que los amparaba.

Estructura del Sermón I. El lema en que se basa toda la arquitectura del sermón es el mismo que luego servirá para predicar el VII: Bonum certamen certavi, Cursum consummavi, fidem servavi: in reliquo reposita est mihi corona justitiae (San Pablo, Epístola a Timoteo, 4), aunque inicia el sermón con otra cita de San Pablo, mismo lugar, que dice: Qui certat in agone non coronatur nisi legitime certaverit.

En el exordio, Beristáin asegura que no hará la historia del ejército español durante los siglos anteriores, sino sólo la de los soldados que murieron en la guerra del Rosellón: "No, Señor, prediquen enhorabuena otros y levanten hasta el cielo [...] los elogios debidos a los militares españoles de otros siglos" (I, p. 3). Sus premisas, que desarrollará en el cuerpo del sermón, son las siguientes: los soldados muertos en la guerra contra Francia son justos porque "pelearon en una buena guerra" (I, p. 5); perdie- 
ron la vida, pero salvaron la fe que debían, resguardando así su lealtad a Dios y al rey, y por ello han sido "coronados en la gloria" (id.). El resto del sermón queda pues dividido en las tres partes así anunciadas en el exordio.

I. Bonum certamen certavi. "El honor de nuestros soldados difuntos es haber peleado en una buena guerra [...] porque ha sido una guerra justa". Así comienza Beristáin la primera parte de su oración. "Jamás la España se ha empeñado en guerra más justa, más legítima, más necesaria"' (I, p. 6).

La lucha contra Francia se enmarca en la irreligiosidad de los revolucionarios franceses que recusan la libertad del culto católico y de la iglesia. Y esa falta de religiosidad es la que amenaza a los predicadores de España y América. El riesgo que corren España y sus colonias es para ellos enorme, porque las reformas de Carlos III no fueron suficientes para aplacar a los pueblos, y después las torpezas de Carlos IV y de Godoy amenazan con complicar la vida de amplios sectores sociales que hasta ese momento se habían sentido razonablemente seguros. En América, a pesar de que existía un bloqueo de información, llegaban las noticias de la Revolución francesa y de la independencia de los Estados Unidos, y el clima era efervescente. La censura de libros y la prohibición de la entrada a los extranjeros se hace cotidianamente. Al mismo tiempo, se llega a expulsar o a asesinar a grupos de extranjeros residentes en sus fronteras ${ }^{19}$. Así lo indica Beristáin: "España rompe los nudos que la ligaban a Francia luego que éstos le son ignominiosos, y pone en su lugar cadenas que prohiben la comunicación con unas gentes sacrílegamente contagiadas, y defiende la entrada a tales monstruos de abominación" (I, pp. 7-8).

Beristáin no dice que el anhelo independentista de las colonias americanas se vio alentado por el Tratado de París (1783), por el que España reconoció la independencia de las colonias inglesas. Las colonias habían invocado el derecho a la insurgencia como uno de los derechos fundamentales de los pueblos, que nadie les podía arrebatar. Consignaron en su Constitución la igualdad de todos los hombres sin distinción, su igualdad política y su derecho a elegir a sus representantes; abogaron por la descentralización administrativa y política proclamando la soberanía de los estados.

${ }^{19}$ Julio Zárate, op. cit., pp. vi y 30 y Richard Herr, op. cit., p. 311. 
Carlos III, llevado por su enemistad contra Inglaterra, cometió el error histórico de amparar ese movimiento, que sin duda influyó decisivamente en los insurgentes americanos. Según Julio Zárate, "España quedó desde ese momento dominadora solamente de hecho de sus vastos territorios"'20.

De los franceses dice Beristáin que "se reparten como furias del averno, con las mechas encendidas, mojadas todavía con la inocente sangre de su rey para incendiar las cuatro partes del orbe, inspirando como sierpes venenosas la ponzoña pestilente de sus máximas abominables: son los franceses pérfidos como los judíos, falaces como los griegos, crueles y feroces como los scitas, impíos, sacrílegos, horribles... ¿como quiénes, si son en la maldad los primogénitos del diablo? Como su padre"' (I, p. 8).

Esta andanada de improperios no consigue sino un efecto adormecedor en el oyente o el lector. La retórica acumulativa, a la que es muy aficionado Beristáin, hace perder sentido a las palabras. Sólo quienes estaban de antemano convencidos de la "justa guerra" española pudieron prestar oídos a tan hiperbólicos insultos. El orador no trata de convencer a su auditorio, al que ya supone convencido. En los sermones, Beristáin deja de lado todo análisis, toda reflexión para convertirlos en actos pretendidamente paroxísticos. Se trata de una oración vacía de razón, llena de sentimientos viscerales, surgida únicamente de la pasión antifrancesa y del miedo a la reacción que se pueda producir en las colonias.

Pero nosostros estaríamos también ciegos ante la historia si no supiésemos ver en la oración de Beristáin la proclamación de un punto de vista - discutible, equivocado, pero muy realde un cierto sector de la población novohispana. Él es el portavoz de una clase que ve en la tutela española sobre las colonias la mano de Dios. La mano ordenadora y civilizadora que les ha beneficiado durante cerca de tres siglos, que les ha hecho ricos y cultos y les ha dado seguridad. Es una clase ciega ante los giros políticos y sociales que se están dando en muchos países. Beristáin dice:

Españoles: veinte y cuatro millones de estos bárbaros quieren turbar vuestra quietud, mudar vuestras costumbres y, con la feliz lisonja de limaros unos grillos que no tenéis ${ }^{21}$, aprisionar vuestra liber-

20 Julio Zárate, op. cit., p. 29.

${ }^{21}$ Las cursivas son mías. 
- tad y haceros infelices sobre la tierra. Españoles: ellos pretenden derribar del trono a vuestro rey, para sentarse luego a dictar leyes sangrientas y de muerte [...] ellos solicitan arrancar de vuestros pechos la religión y ya empezaron a profanar vuestros templos, vuestras aras y vuestros sacerdotes (I, p. 9).

El conde de Aranda, estadista lúcido y crítico, había escrito al rey en 1783 que era muy difícil conservar las colonias de España, pues había "dificultad de socorrerlas cuando puedan tener necesidad [...] son numerosas las vejaciones de algunos de los gobernadores contra los desgraciados habitantes; la distancia de la autoridad suprema a la que tienen necesidad de ocurrir para que se atiendan sus quejas [...] hace que se necesiten años enteros antes que se haga justicia a sus reclamaciones [.. . ] todas estas circunstancias no pueden dejar de hacer descontentos entre los habitantes de América y obligarlos a esforzarse para obtener la independencia tan luego como se les presente la ocasión"'22.

Lo mencionado por Aranda y las constantes rebeliones del siglo XVIII son factores ausentes de la oratoria de Beristáin.

II. Cursum consummavi. España es comparada con Raquel cuando llora la pérdida de sus hijos. " $\mathrm{O} O \mathrm{Oh}$, que son muchos los que faltan y no hay consuelo!'” (I, p. 15). Y entre todos los soldados que menciona, no falta el general Antonio Ricardos, que estaba al frente del ejército y cuya muerte causó la desbandada general de los "heroicos soldados españoles".

Antonio Ricardos había combatido en Italia entre 1744 y 1748; reorganizó el ejército español en Nueva España veinte años más tarde, y luego dirigió la fracasada expedición española a Argelia. Fue desterrado y cayó en desgracia con Floridablanca, y más tarde fue rehabilitado y nombrado capitán general de $\mathrm{Ca}$ taluña. Por ello se encontró dirigiendo la ofensiva del ejército español en el Pirineo y el Rosellón en 1793.

Hasta su muerte en campaña, las tropas españolas habían conseguido frenar la entrada de los franceses, pero el nombramiento del general Coquille-Dugommier, vencedor de Tolon, y la ayuda recibida por el ejército francés desde el gobierno, hicieron que se consolidara el ejército enemigo. Así, en el otoño de

${ }^{22}$ Memoria secreta presentada al rey Carlos $I I I$ (...) sobre la independencia de las colonias inglesas. . citado por ZÁRATE, op. cit., pp. 367 ss. 
1793 éste logró penetrar en Cataluña. No cabe duda que la muerte de Ricardos contribuyó al giro que dio la campaña ${ }^{23}$.

En una enumeración decreciente, Beristáin pasa revista a todos los que lloran a los muertos de la guerra: "Todos los rcynos de la monarquía lloran, en cada reyno todas las provincias, en cada provincia todos los pueblos y en cada pueblo todas las casas se visten de luto, gimen y lamentan la pérdida del hijo, o del padre, o del hermano, o del esposo o del paisano, o del amigo o del señor o del criado'" (I, p. 17). Pero estas muertes se lloran, según la perspectiva que les otorga Beristáin, no como un dolor personal o humano, sino porque permiten que Francia haga avances en territorio español.

En seguida, Beristáin afirma que España resistió y atacó a Francia: "Asaltaste sus castillos, bloqueaste sus puertos, le ganaste batallas, la escarmentaste, la burlaste, la confundiste por espacio de veinte meses"' (I, p. 18).

Cuando Beristáin pronunció este sermón (noviembre de 1794), ya se conocía en las colonias la noticia de la derrota de España. Pero en esta oración este hecho ni siquiera se sugiere; por el contrario, dice el orador: "Vivos ellos, tú venciste, y aunque el valor de tus tropas no se ha sepultado con los muertos, esos faltan a tu esplendor" (I, p. 18).

III. Fidem servavi. Según Beristáin, los españoles son fieles por naturaleza:

Los españoles aprenden desde los pechos de sus madres la fidelidad, la lealtad, la obediencia a sus soberanos. No es necesario que el augusto Carlos publique decretos, ni mande tomar las armas, basta circular por todo el ámbito de su monarquía la noticia sencilla del horrible atentado, del sacrilegio inaudito que cometió la Francia contra el virtuoso y amable Luis XVI, para que los nobles y los ciudadanos, los grandes y los pueblos, los ancianos y los jóvenes $[\ldots]$ le ofrezcan sus haciendas, sus personas mismas contra los execrables franceses (I, pp. 19-20).

Aquí Beristáin extiende a un período mucho mayor el hecho (que se dio realmente al inicio de la campaña) de la unanimidad

${ }^{23}$ Para una información más completa, véase Richard Herr, op. cit., pp. 277-296 y, sobre la respuesta española a la guerra, el capítulo siguiente de la misma obra, pp. 297-315. 
de la lucha contra los franceses. Efectivamente, después de la ejecución de Luis XVI muchos españoles rechazaron la Revolución, que antes había sido admirada por bastantes españoles progresistas. Sin embargo, este entusiasmo bélico inicial no se renovó sino hasta que se llevó a cabo la pérdida del Rosellón, al año siguiente, $y$ por tanto, no fue una actitud continuada. Por otra parte, Cataluña luchó denodadamente para no pasar a ser francesa, pero esto no ocurrió de la misma manera en el País Vasco y Navarra, donde existían serias dudas acerca de una posible traición de las autoridades y de los pueblos de Guipúzcoa y San Sebastián ${ }^{24}$.

En términos generales, las observaciones de Beristáin pueden considerarse como correctas, si bien su interpretación es tendenciosa y poco mesurada. En lo que concierne a las colonias, estos defectos son visibles en la arenga que declama para conseguir que los mexicanos se decidan a luchar y a donar sus bienes y haciendas para ser considerados fieles vasallos de España:

¡Fidelidad santa, ven! Pero he dicho mal, porque te estoy viendo resplandeciente en mi auditorio... atiza con esa hacha luminosa el fuego que encendiste y has mantenido inextinguible por dos siglos y medio en el corazón de los mexicanos. Haz que brille como el de sus hermanos los Europeos. Españoles somos todos... todos somos enemigos de la Francia, porque todos abominamos a los que se atrevieron a quitar la vida al Vice Dios de aquel imperio (I, p. 22).

Y el canónigo sigue la arenga para que los mexicanos pasen a sustituir a los soldados españoles muertos en la defensa contra Francia. Sin embargo, la colonia no podía, ni siquiera en sus capas más altas, sentirse demasiado ligada a aquellos acontecimientos. Sólo se consiguió, y con no poco trabajo, que algunos hacendados y familias acomodadas dieran dinero para armar un

${ }^{24}$ En abril de 1794 Francia expulsó al ejército español del Rosellón y poco después pensó seriamente anexarse Cataluña. En mayo, Robespierre propuso la independencia del territorio catalán, que pasaría, bajo la tutela francesa, a convertirse en una república aliada. La propuesta, demasiado fantasiosa, no prosperó. En julio se proclamó la caída de Guipúzcoa y de San Sebastián. En noviembre de ese mismo año se producía la capitulación de Figueras, e inmediatamente, la caída de Gerona. Richard Herr, op. cit., pp. 301-315. 
regimiento en la península. Los mexicanos estaban -y lo sabían - amenazados directamente por los estados europeos, que veían en las colonias una gran riqueza y un importante germen de inestabilidad. En 1793, Brissot, cabeza visible de los girondinos, "proponía al comité de Salud Pública una expedición militar a las posesiones españolas en América"'25. Al mismo tiempo, el general francés Damouriez señalaba la conveniencia de que Francia se aliara con Inglaterra - contando con el apoyo de Estados Unidos - para independizar a las colonias.

Para los mexicanos, el panorama interno era más preocupante que la lejana amenaza europea, pues en 1786 las sequías periódicas que padecía la colonia cada once años fueron aún más severas y culminaron con la llamada "gran hambre"'. Las castas, los indios y los negros se sintieron todavía más desprotegidos y más descontentos. El gobierno virreinal, por su lado, echó marcha atrás en las reformas que había iniciado con el fin de mejorar la situación de estos sectores e intentó contener los avances ilustrados en Nueva España por miedo a que surgiera un brote violento como el de la Revolución francesa.

Por todo ello, la juventud criolla se hizo más radical en su exigencia de reformas y recibió con mayor entusiasmo las noticias que llegaban de Francia y de los Estados Unidos. Esa juventud quería para su patria más reformas y cambios que los que se producían en la lenta administración colonial.

Estos hechos llevaron a unos 200 criollos a conspirar en Guadalajara en 1793, acaudillados por fray Juan Antonio de Montenegro. Al año siguiente se descubrió otra conjura, esta vez en la ciudad de México, que era capitaneada por el criollo Juan Guerrero. En 1799 se descubrió la llamada "conspiración de los machetes", dirigida por el criollo Pedro de la Portilla ${ }^{26}$.

En estas delicadas circunstancias es dudoso que Beristáin pudiera conseguir la adhesión que pretendía de los mexicanos. Al final, dice: "Publicad conmigo que España nunca fue más belicosa y feliz [...] que cuanto más religiosa en sus reyes y soldados"' (I, p. 27).

${ }^{25}$ Agustín Cué Cánovas, Historia económica y social de México, 1521-1854, Trillas, México, 1981, p. 200.

${ }^{26}$ Daniel Cosío Villegas et al., Historia mínima de México, El Colegio de México, México, 1973, pp. 80-82. 
Sermón VII: 'La triple fidelidad coronada. Elogio de los españoles muertos por los franceses el. día dos de mayo de 1808',27

Como he dicho al principio, este sermón enlaza temáticamente con el que acabamos de ver (de 1794), pues se trata de otra diatriba contra la nación francesa, al mismo tiempo que un elogio de los militares españoles. Son las mismas premisas repetidas: la amenaza política se mezcla con la religiosa; contra ambas luchan los españoles, fieles a su patria, a su Dios y a su rey (la triple fidelidad). También en este sermón brillan por su ausencia las referencias históricas o los hechos concretos, y la realidad queda mediatizada para halagar a un colectivo de la sociedad hispánica, el ejército, que en aquellos momentos delicadísimos se sabía vital para las colonias y para la península.

La estructura del. sermón. "La triple fidelidad. . "' es un elogio más breve que el que acabamos de ver, y consta de un exordio y dos partes. En el exordio se habla de los españoles difuntos de nuevo en el contexto de una guerra santa: los muertos son los mártires de la religión y la fidelidad y fueron "sacrificados por los infames satélites del pertubador de la iglesia y del mundo, Napoleón" (7, p. 106).

El orador pretende, según él mismo dice, resumir las virtudes de estos hombres, pues "por sí mismas se insinúan y recomiendan".

Terminado el brevísimo exordio, Beristáin hace una vez más una interpretación sui generis de la historia reciente, pasando por alto la actuación de Manuel Godoy en sus tratos con Napoleón y las poco claras intrigas de Fernando contra sus padres, así como la abdicación de Carlos IV. Nada de esto se menciona en el sermón, a pesar de que, de nuevo, todos estos hechos eran conocidos en las colonias y habían preocupado seriamente a las autoridades virreinales y al ayuntamiento.

Por el contrario, para Beristáin, Fernando es "el inocente y sencillo, tanto como justo y amable [...] a quien la astuta serpiente Bonaparte había arrastrado a Bayona para quitarle el cetro de sus abuelos"' (7, p. 108). Pero el pueblo español no podía dejar abandonado a Fernando, "príncipe jurado de Asturias, rey proclamado de la nación entera, por un vil gusano de Córcega,

${ }^{27}$ La felicidad de las armas de España, pp. 104-114. 
por el usurpador de la diadema de los Luises, por el fraudulento embaucador de la Europa" (VII, p. 110).

Sin embargo, a pesar de estos escandalosos "olvidos", Beristáin acierta al ver que España se revuelve contra Napoleón, en parte por cuestiones religiosas, pues el cónsul pensaba equivocadamente que la reacción del pueblo sería la contraria: que se sentiría dichoso por poder prescindir de aquel rey más bien ridículo, de los frailes, de la Inquisición... y no es así. Pero esto no quiere decir que no hubiera en España gente, y gente muy importante, que vio en la intervención francesa una forma de integrar a España en la Europa de las Luces y de la libertad, y con ello, la oportunidad de terminar de una vez por todas con el modo de producción semifeudal que pervivía y con la tiranía eclesiástica. Ninguno de estos elementos es mencionado por Beristáin, pues su discurso es monolítico y en él no caben las matizaciones. Él está a favor de la-corona, aunque quien la lleve sea un inepto; de la patria española, aunque ésta esté arruinando a Nueva España; a favor de la iglesia, aunque su papel en la colonia fuese cada vez más negativo.

En la segunda parte del sermón, Beristáin anuncia que la recompensa de la fidelidad de los españoles no es otra que la salvación. Y aquí aparece por primera vez la otra voz, el otro punto de vista, el de los clérigos afrancesados de la Colonia:

Habéis tenido la herética osadía de predicar, anunciar, prometer y asegurar bajo vuestra palabra la gloria eterna a los facciosos y rebeldes a su rey legítimo, a los asesinos y ladrones [...] viles e inconsecuentes. ¿Sólo vuestra causa es justa y del agrado de Dios?.. Vuestra filosofía es muy brutal, y muy herética vuestra teología, y yo predico, no blasfemias, como ha dicho ya alguno de vosotros, sino la doctrina que he aprendido en los libros santos de Dios y de los doctores de su iglesia (VII, pp. 112-113).

Con motivo de la invasión francesa, los criollos y otras capas sociales habían visto por fin la oportunidad tan deseada de conseguir la independencia. La industria local había logrado suplir las importaciones españolas desde 1796; la libertad de comercio $^{28}$ forzosa había convencido a los mexicanos de las ventajas de este tipo de comercio sobre el del monopolio español, y la colonia veía

${ }^{28}$ Por medio de la orden expedida por Carlos III, Nueva España y Venezuela pudieron ejercer el libre comercio con otros países desde 1789 . 
claramente que podía ser autosuficiente. Un buen día, aparecieron en la catedral de México estos versos tan significativos:
Abre los ojos, pueblo mexicano, y aprovecha ocasión tan oportuna. Amados compatriotas, en la mano las libertades ha dispuesto la fortuna; si ahora no sacudís el yugo hispano miserables seréis sin duda alguna ${ }^{29}$.

Al mismo tiempo, la lista de los mexicanos encarcelados por motivos políticos crece, comenzando por fray Melchor de Talamantes, el síndico J. Primo de Verdad y el regidor Juan de Azcárate. El 15 de septiembre de 1808, los españoles influyentes quitan el mando al virrey Iturrigaray, a quien consideran demasiado "blando", y ponen en su lugar a un militar semidesconocido y al arzobispo de México, F. Lizana y Beaumont. Muchos miembros del ayuntamiento son encarcelados; el clero criollo comienza a reaccionar y ataca a los españoles y sus aliados, y significativamente, a Beristáin de Souza, el predicador que de manera más visible defiende la postura española. A pesar de las advertencias del orador poblano, la ola revolucionaria comienza a extenderse por todo el reino.

Los cinco restantes sermones de La felicidad de las armas de España

En los cinco restantes sermones panegíricos de la recopilación $L a$ felicidad de las armas de España, Beristáin se propuso escribir y predicar las glorias y las derrotas de las armas españolas, relacionando las primeras con la épocas de piedad y las segundas con las impiedades o herejías de los militares en los diversos momentos históricos que trata. En el primero de estos sermones (segundo de la recopilación), "Elogio de los militares..." $(1798)^{30}$, el orador recuerda en el exordio el primer sermón en el que elogió la valentía de los militares muertos en la guerra del Rosellón contra Francia. En esta segunda oración se propone "otro objeto

${ }^{29}$ Citado por Luis GonZÁLEz, "El periodo formativo", en Historia minima de México, p. 83.

30 "Elogio fúnebre de los militares españoles difuntos, pronunciado en la Metropolitana de México el año de 1798 en presencia del virrey don Miguel José de Azanza", pp. 31-49 de la recopilación La felicidad de las armas de España. 
más universal, aunque no menos interesante', que es glosar la historia de las armas españolas y de sus militares, "que fueron fuertes, triunfantes, conquistadores por la fe pura y la religión inmaculada que abrigaron en sus pechos" (II, p. 33). Esta es la premisa que guiará los cinco sermones dedicados a este tema, en los que la religión, la conquista y la guerra vienen a ser términos correlativos (ya hemos visto que Beristáin veía la guerra como "cruzada"). Cuando la religión no presidía los actos de los militares, Beristáin se encuentra con "las desgracias de los reyes, las traiciones de los generales, la cobardía de los soldados, la sublevación de los pueblos y la ruina total de las monarquías" (II, p. 34). Así, Beristáin establecía una relación directa entre la religiosidad y el triunfo; la falta de fe y la derrota y el caos. Esta premisa preside los parcos resultados literarios de los cinco sermones que, con brevedad, vamos a glosar. Tan peregrino planteamiento no deja de ser interesante para entender la mentalidad de un sector social que, a finales del siglo xvin, daba por supuesta la intervención divina en las batallas, y justificaba sus resultados como si de un "juicio de Dios" medieval se tratara. Sin embargo, como ya hemos visto con la guerra del Rosellón, el orador se reservaba el derecho de modificar los hechos históricos a favor y mayor gloria de su premisa original (fe cristiana $=$ victoria bélica) o simplemente, podía cambiar sus juicios con la historia: en este segundo sermón de La felicidad... por ejemplo, Francia ya no es la terrible devoradora de hombres, sino la "hermana Samaria", y aquella guerra "no ha sido empero una guerra de mortandad ni de sangre'". Como se ve, la traducción que hacía Beristáin de la política española traía como consecuencia que sus sermones se resintieran de falta de credibilidad, pues lo que ayer (1794) era terrible y digno de espantosas diatribas antifrancesas, hoy (1798) podía ser dulce fraternidad europea. Mezclar la religión con la política podía ser, como vemos, un proceso lleno de confusiones.

Una vez terminado el brevísimo exordio, Beristáin entra en la materia del sermón basándose en una sentencia de San Pablo: Senes per fidem vicerunt regna, facti sunt fortes in bello, castra verterunt exterorum $^{31}$ (Epístola a los hebreos, 11, 8-9).

Su relación de los hechos comienza con Eurico, que fundó la

${ }^{31}$ La afición de Beristáin a tomar citas de San Pablo es recurrente en todos sus sermones. Tal vez la intolerancia del converso romano iba en consonancia con la suya. 
monarquía goda en España, con quien Beristáin abre la galería de personajes ilustres que muestra el carácter de los guerreros españoles "pintando al natural en los sucesos incontextables de la nación más católica y más guerrera que ha ocupado el ámbito de dos mundos" (II, p. 34). Después del elogio a Eurico, Alarico fue "vencido y muerto por Clodoveo en la batalla de Vougle, porque, sobre ser arriano, fue hombre cruel, altivo, impío y despreciador acérrimo del santuario"' (II, p. 35). El orador menciona a Teodorico, Alarico, Teudis, Leovigildo, Recaredo, Viterico, y los militares Sisebuto, Recesvinto, Wamba y un largo etcétera hasta llegar a Alonso $\mathrm{V}$, a quien dedica un fragmento que no tiene desperdicio:

Alonso $V$ toma el cetro: religiosísimo, enemigo jurado de los infieles, celosísimo del culto de Dios y del honor de sus ministros, reedifica la catedral de León destruida por Almanzor, repone a las iglesias los bienes que habían perdido y... ¿y qué? ¿qué había de suceder? Derrota al invicto hasta entonces Mohamad en la famosa y nunca bastantemente celebrada batalla de Catalañazor (II, p. 47).

Para poner el broche de oro, se le ocurre al erudito poblano hacer un encendido elogio del conquistador español, caldeando los siempre sensibles y agitados ánimos de amplios sectores criollos, al decir, que México ha sido afortunado por haber sido regado con la sangre religiosa de sus conquistadores. A éstos los llama invictos y piadosos, y concluye haciendo un equivocado retrato del suelo novohispano donde para él "todavía no hay maleza [...] por el celo de sus ministros y por la piedad y religión de sus hijos. No hay todavía donde se críen y escondan víboras venenosas, no carcoma ni polilla infernal que roa el tronco ni las raíces de este árbol sagrado" (II, p. 48). En este párrafo final no sólo llama la atención el estilo del vituperio, frecuente en sus sermones, sino también la voluntad de esconder o enmascarar una agitación que venía ya desde hacía tiempo, pero que durante esos años finales del siglo comenzó a hacerse demasiado evidente para poder ser ocultada.

Los siguientes sermones de la recopilación siguen el mismo esquema de este inicial: el tercer "Elogio" (1800) ${ }^{32}$ recorre la historia militar de España desde Sancho de Navarra, que luchó

32 "Elogio fúnebre de los militares españoles difuntos pronunciado en la Metropolitana de México el año de 1800 en presencia del virey D. Félix Berenguer de Marquina", pp. 50-63 de La felicidad de las armas de España. 
contra los moros y fue el "primer rey de España", introductor de la orden de Cluny, organizador del concilio de Pamplona para el restablecimiento de la disciplina eclesiástica y a quien, naturalmente, le sonrió la fortuna en todas sus batallas. Luego Beristáin habla, siempre estableciendo el paradigna fe $=$ victoria, de Fernando el Magno y sus sucesores. Concluye que "con tales reyes fueron los españoles felices" (III, p. 56) y menciona todavía a Alfonso VIII, Fernando III de Castilla y Jaime I, a quien llama "Jaime de Aragón", con cuya figura concluye este sermón, no sin antes exclamar: "¡Oh militares, defensores de la religión! ¡Oh religión, alma y espíritu de nuestros militares!' (III, p. 63).

El cuarto "Elogio" (1803) ${ }^{33}$ se propone continuar "este hilo precioso" de la historia militar de España, hablando de Alfonso $\mathrm{X}$, a quien Beristáin ve "conquistador y religioso a un mismo tiempo" (IV, p. 67), según anuncia en el exordio.

Sin embargo, la historia de Alfonso X de Castilla es demasiado conocida para su auditorio como para que el orador pase por alto ciertos hechos negativos de su ilustre vida. Por ello debe resolver el problema que esto le plantea para que el sermón quepa en las coordenadas o en las premisas que él mismo se ha impuesto. Aquí también debe probar que Dios da victorias a los buenos y fracasos y derrotas a los que no cumplen con la religión. Por tanto, los hechos negativos de la vida de Alfonso X deben ser expuestos de manera que no echen por tierra las pedagógicas pretensiones del orador, quien dice: "Pero Alfonso sin embargo (me dirá un filósofo deísta), sufrió en los últimos años los mayores desaires de la fortuna, pues despojado del reyno por su hijo D. Sancho fue reducido a ser rey sólo de la siempre leal y fidelísima Sevilla. ¿Dónde pues está la dicha que debía ser el fruto de su piedad?' (IV, p. 68). Efectivamente, ése era el problema, y era un inconveniente que se le debía presentar al orador una y otra vez al escribir sus sermones elogiosos, pues la vida no es tan perfecta como el arte y no es tan fácil en ella hacer coincidir el premio con la bondad y el castigo con su opuesto. Beristáin debe compaginar de alguna manera la desgracia de Alfonso con la bondad que le ha atribuido antes. Y para ello recurre a la mención de las muertes del infante Don Fadrique y de Simón Ruiz de los Cameros, que se le atribuyeron, y que el orador no había mentado antes.

33 'QQuarto elogio fúnebre de los militares españoles difuntos pronunciado en la Metropolitana de México el año de 1803 en presencia del virey d. José de Iturrigarai", pp. 64-77 de La felicidad de las armas de España. 
Beristáin se vuelve ahora casi implacable con Alfonso, pues un supuesto comentario del rey serviría él solo para justificar todas sus desgracias: "[Alfonso] se atrevió a decir que si Dios le hubiese llamado por consejero cuando hizo el mundo, le hubiera dado otro plan y hecho algunas advertencias al Omnipotente" (IV, p. 69). Sin embargo, acaba comparando a Alfonso con el rey David, pues por haber pecado "alguna vez" no merece ser descalificado ni desconocido como el gran rey que fue.

El hijo de Alfonso, Sancho, sirve para contrastar la magnífica figura del anterior. Además, en este cuarto "Elogio" aparecen también Alonso Pérez de Guzmán, Pelayo Pérez Correa, Pedro III de Aragón, Fernando IV de Castilla y Alfonso XI, con quien concluye la relación. A este último, el cielo lo protegió por su bondad: "[Con] Quatrocientos mil infantes y sesenta mil caballos reunió [el moro] todo el poder del África, para subyugar segunda vez a la fiel España. Alfonso no pudo oponerles sino quarenta mil peones y diez y ocho mil gimetes; pero el cielo, a quien era grata la piedad de Alfonso, le dio el más completo triunfo" (IV, p. 76). Y apostilla: "El impío no lo creerá, pero lo vio España y lo creyó Roma”.

Quinto "Elogio" (1805) $)^{34}$. En el exordio nuevamente resume el contenido de los "Elogios" anteriores (V, pp. 78-79). El relato de las hazañas de los militares se inicia esta vez con la vida de Pedro el Cruel. Beristáin reseña todos sus crímenes y sobre todo su alianza con los moros, "enemigos del nombre cristiano y español" (V, p. 80). "Esta fue su conducta, esta su religión... ¿Y cuáles fueron sus sucesos militares? Su armada deshecha en las costas del Mediterráneo; sus tierras invadidas de tropas extrañas; sus vasallos conspirados contra él por todas partes. . Éste es el triunfo de la irreligión, ésta la victoria de la impiedad"' (V, p. 81).

La relación ejemplarizante continúa con Pedro IV de Aragón, Carlos II de Navarra, el portugués Pedro I, Enrique II de Castilla y una larga lista que concluye con Fernando ${ }^{35}$, abuelo del rey católico, con cuyo reinado dará por finalizada esta serie de "Elogios".

En el sexto y último "Elogio" $(1810)^{36}$, "Elogio de los mi-

34 “"Elogio fúnebre de los militares españoles difuntos pronunciado en la Metropolitana de México el año de 1805, en presencia de la guarnición de la plaza de México', pp. 78-91 de La felicidad de las armas de España.

35 Por cierto que no menciona el origen judío de Fernando el Católico.

36 “Elogio fúnebre de los militares españoles difuntos pronunciado en la 
litares" de España, Beristáin se ocupa únicamente de la época de los Reyes Católicos: suma y ejemplo de las virtudes de ese pueblo. En el acostumbrado exordio, advierte que en todas sus oraciones se ha empeñado en "'manifestar con sucesos positivos e incontextables que la felicidad de nuestras armas fue siempre proporcionada a la virtud y piedad de los caudillos y soldados, y que la fe y la religión hicieron a los españoles antiguos valientes, conquistadores y triunfantes" (VI, p. 93). El orador relata aquí con encomiable entusiasmo la agresiva actuación de Alonso V de Portugal, la batalla de Toro y las de Aticnza, Caracena, Burgos y la conquista de las islas Canarias. En este punto Beristáin opina que "Ya el ciclo iba premiando la piedad de la católica reyna fuera del continente de la península. Mas como ella aumentaba cada día los méritos, era preciso que el remunerador de las virtudes aumentase también los premios" (VI, pp. 96-97).

Según la óptica bajo la que traza Beristáin todos sus "Elogios", era perfectamente lógico que Dios recompensara a los reyes con el regalo del Nuevo Mundo. Isabel y Fernando no sólo unificaron España, sino que también lucharon contra la temible herejía al expulsar a los moros y a los judíos. Con esta acción "purificaron" sus reinos y velaron por la ortodoxia al impulsar la Inquisición. Al hablar del "Santo Tribunal" Beristáin se exalta y emociona, y nos hace ver con mayor claridad, si esto es posible, que a pesar de su cultura y de su erudición era hombre poco tolerante y no era ni podía ser un ilustrado: "Aquí quisiera yo detenerme para ponderar la importancia de este servicio hecho a la religión y al estado, los innumerables bienes que ha producido [la Inquisición] a la iglesia y a los dominios de España, y la atrocidad de las calumnias con que los impíos y libertinos han pretendido desacreditar y echar por tierra esta columna de la fe y baluarte de la paz de los pueblos"' (VI, p. 97).

Decir estas palabras en 1810 equivalía no sólo a negar una verdad histórica ya asumida en aquella época, sino negar la libertad de conciencia y abogar por el método de la represión más brutal para mantener "la paz de los pueblos". Desde finales del siglo anterior, el mundo civilizado luchaba por los derechos del hombre. Llamar libertinos e impíos a quienes denostaban a la

Metropolitana de México en el año de 1810 en presencia del virrey don Francisco Venegas", pp. 92-103 de La felicidad de las armas de España. 
Inquisición no era sólo un error de perspectiva histórica, sino un verdadero anacronismo ${ }^{37}$. Según prosigue Beristáin en su "Elogio", el haber impulsado la Inquisición fue un hecho definitivo para que Dios diera a Isabel el "premio singular" del descubrimiento de América.

Con él, Dios concede a los reyes la oportunidad de desterrar la idolatría de muy amplias zonas del planeta: "Las Indias Occidentales se decubren felizmente; tremola en los templos de la idolatría la insignia del crucificado"'. Recordando ese momento, Beristáin se siente "transportado también de júbilo" y pregunta "¿quiénes son esos pueblos, hasta ahora desconocidos que con tanta velocidad vienen volando al gremio de la iglesia?" y responde con una frase ciertamente extraña en 1810: "Estos son los indios que Isabel ha redimido con sus joyas de la esclavitud del demonio" (VI, p. 103). Y en una visión idílica que contrasta con la convulsionada realidad del momento, agrega: "Sí, las riquezas del Nuevo Mundo que has descubierto [...] se consagrarán al Dios de Israel, y las invertirás en templos... en las remesas de operarios evangélicos, de labradores y artesanos, de maestros y jueces que hagan este nuevo mundo digno de tu religión y tu grandeza" (VI, p. 104).

Para el predicador no existen ni las epidemias devastadoras, ni las matanzas de indios, ni los abusos del clero ampliamente aireadas desde el principio de la conquista, ni el descontento patente de los habitantes del país, que en cambio Abad y Queipo o el conde de Aranda habían observado.

En el "Elogio", todos estos hechos quedaban censurados y borrados. Situado en el centro mismo del conflicto colonial, Beristáin sólo quiso transmitir una irreal, inexacta y ahistórica perspectiva cuya invalidez se reveló inmediatamente con la revolución de Independencia.

"Discurso político-moral y cristiano"' (1809)38. El tema bajo el cual

${ }^{37}$ Sobre la Inquisición en estos últimos tiempos coloniales véase el ponderado estudio de Henry Kamen, la Inquisición española, $2^{\mathrm{a}}$ ed., Crítica, Barcelona, 1985, pp. 326-369, y para la Nueva España, Solange Alberro, Inquisición y sociedad en México, 1571-1700, F.C.E., México, 1988, pp. 186-187.

38 "Discurso político-moral y cristiano que en los solemnes cultos que rinde al Santísimo Sacramento en los días de carnaval la Real Congregación de eclesiásticos oblatos de México, pronunció ...", Impta. de Fernández de Jáuregui, México, 1809. 
se estructura el "Discurso" es: Honora patrem tuum et matrem, ut sis longaevus super terram (Éx., 20, 12).

Con esta frase bíblica, se dirigía a la "Suprema Junta Central Gubernativa de España y de su Indias", a quien iba dedicado el sermón, cuyos términos eran puramente políticos. En este "Discurso", Beristáin deja constancia de su amor por la Madre Patria y de la necesidad de lograr que sus compatriotas compartieran este amor. Así lo explica él mismo en el exordio: "Yo vengo a hablar de una materia propia de la ley y religión que profesamos, y propia también del tiempo y circunstancias en que nos vemos; materia en que consiste nuestra felicidad temporal y también eterna [...] en la que desahogaré una gran parte de los sentimientos que poseo y con que siempre se ha alimentado mi alma y que deseo arraigar más y más en las vuestras" (pp. 2-3).

El orador descarta ocuparse aquí del primer padre, que es Dios, y decide hablar únicamente del agradecimiento y fidelidad que se deben al segundo, que es el rey de España. Según Beristáin, la madre "es la invicta y católica nación española". El fruto de este padre y esta madre es México, pero por extensión toda la América.

Como es obvio, este fruto sólo puede ser descrito por Beristáin con las tintas más cargadas de admiración hiperbólica. Esta nación es, para mayor honra de tan nobles padres, una "capital populosa y hermosísima, capital del reyno más opulento de la tierra, trono de la religión inmaculada, silla de las ciencias, emporio de las más bellas artes, centro de la piedad, de la urbanidad y de la riqueza" (p. 5).

Esa ciudad y ese reino entero de cuento de hadas, debía sus magníficas prendas, las leyes que la regían y la educación, la felicidad y todo lo que tenía, a los Reyes Católicos y a Carlos V, “"que te sacó del poder de la barbarie y tiranía y por medio de sus enviados sacerdotes te libró del demonio y del infierno" (p. 7). También debe México — según Beristáin- gratitud a Felipe II y todos los demás reyes que "como amorosos padres" lo dotaron, fomentaron su riqueza y lo engrandecieron.

En este punto, Beristáin se remonta a la época anterior a la conquista para contrastar ese mundo maravilloso surgido de la generosidad y piedad de los reyes españoles; el México indio era para el poblano "un pueblo bárbaro y grosero, sujeto a unos déspotas que después de exprimir toda la sustancia a sus vasallos y de engrosarse con el sudor de su rostro, sacrificaban a sus hijos en las aras impuras de sus ídolos abomirables" (pp. 7-8). Los 
mexicanos no conocían al verdadero Dios, y solamente este hecho ya invalidaba el reconocimiento de su cultura por parte de algunos sectores pro-españoles. El desconocimiento de la "verdadera religión" sumía a los pueblos indígenas - según Beristáin- en un caos civil y social y en una dictadura sangrienta que vedaba a los súbditos toda la libertad y riqueza. Este cuadro apocalíptico fue borrado, siempre bajo la perspectiva del erudito, gracias a los reyes de España que sacaron al pueblo mexicano "de la nada a la luz, de la ignorancia al conocimiento de las ciencias, de la miseria a la felicidad, de la pobreza a la abundancia, de la grosería de costumbres a la finura y delicias de la vida racional" (p. 8).

Con estas rotundas afirmaciones Beristáin se enfrentaba tajantemente con la ya sólida corriente criollista que, desde el siglo xvil, buscaba reivindicar la alta cultura indígena ${ }^{39}$. Se enfrentaba también con la propia realidad del país, que por sí sola desmentía aseveraciones tan desmesuradamente optimistas y tan alejadas de la triste condición de la mayoría de los mexicanos, que desde la conquista habían pasado a convertirse en una clase subalterna y explotada. En el punto en que el "Discurso" coincidía con la realidad, es decir, en el hecho de que la Nueva España estaba pasando por un período de autosuficiencia económica, no hacía más que dar la razón a los enemigos que propugnaban una independencia que los liberara de las múltiples trabas administrativas que imponía la metrópoli a la colonia, y que frenaba su desarrollo.

El criollo culto hubiera podido refutar a Beristáin con sólo citar la larga tradición de los Alva Ixtlilxóchitl, de fray Juan de Torquemada o de Carlos de Sigüenza, por sólo hablar de escritores criollos; después vendrían hombres como Francisco Javier Clavijero y otros ${ }^{40}$ a quienes también debió leer nuestro orador.

En su afán por crear afecto y agradecimiento en los mexicanos hacia sus reyes, Beristáin continúa la larga lista de beneficios que piensa que trajo la colonización española a Nueva España:

${ }^{39}$ Jorge Alberto MANRiQue, "Del barroco a la Ilustración", en Daniel Cosío Villegas (coord.), Historia general de México, El Colegio de México, México, 1980, t. 2, pp. 357-446, esp. pp. 336 ss.

${ }^{40}$ Sobre el pensamiento mexicanista véase José María Gallegos Rocafull, El pensamiento mexicano de los siglos xvi y xoii, UNAM, México, 1974, passim y Bernabé Navarro, La introducción de la filosofía en México, UNAM, México, 1948. 
¡Cuántas gracias y privilegios os concedieron [los reyes] que no gozan sus propios vasallos los españoles! En los tribunales sois mirados como menores; las alcabalas y gabelas no se hicieron para vosotros $[\ldots]$ y en todo han mandado $[\ldots]$ los reyes $[\ldots]$ a los virreyes, a los gobernadores, a los obispos, que os traten como a sus hijos tiernos..., que castiguen severamente a quien os oprima y que os guarden y conserven vuestros privilegios y todas vuestras costumbres (pp. 9-10).

Y sigue Beristáin insertando las múltiples ventajas que a los indios mexicanos trajo la dominación española, pero una vez más la realidad es su peor enemiga. La Inquisición, después de una primera etapa en que se ocupó de los judíos portugueses que habían huido de Europa, enjuició también a los indios, que no tenía bajo su jurisdicción, por prácticas hechiceriles o por idolatría, si bien los condenaba tomando en cuenta su calidad de "menores". Los pleitos por los despojos de las tierras de los indios llenaban los tribunales civiles, y las quejas se extendían por todo el territorio. Los diezmos, si no las alcabalas, empobrecían aun más a la población rural. Y el remado de Carlos III agravó la situación de los criollos, que hasta entonces habían podido enriquecerse, apartándolos de los puestos administrativos en los que habían sido una fuerza importante. En 1808, nos dice Luis Villoro $^{41}$, todos los puestos importantes del virreinato, tanto en lo administrativo como en lo eclesiástico y militar, estaban ocupados por españoles. Por otra parte, todos los privilegios locales habían sido barridos a lo largo de los siglos desde la conquista, y singularmente los de los municipios y las comunidades rurales, que no tenían ni voz ni voto en las decisiones centralizadas de la metrópoli ${ }^{42}$. Finalmente, aun omitiendo las rebeliones, durante el siglo xvII proliferaron movimientos campesinos y de mineros que reinvindicaban unos derechos que no tenían. Así se comprobó que el propio sistema político generaba contradicciones que no surgían de un efecto reflejo respecto a otros movimientos internacionales.

Que Beristáin se haya atrevido, en medio de una colonia convulsionada en la mayoría de sus estamentos sociales, a cantar las delicias de un jardín del Edén inexistente, puede constituir un

${ }^{41}$ Lurs Villoro, "La revolución de Independencia", en Daniel Cosío Villegas (coord.), Historia general de México, t. 2, pp. 303-356, esp. p. 307.

${ }^{2}$ A. René Barbosa, La estructura económica de México, SEP, México, 1976, pp. 165 ss. 
enigma. Es como si este hombre hubiese querido con sus palabras, modificar la realidad mágicamente y que de ellas surgiera ese paraíso por él imaginado o deseado. Y es como si esos españoles o esos criollos pro-españoles hubieran querido, durante largo tiempo, tapar el sol con un dedo, ocultar la realidad con palabras. Lo mismo hacía Lorenzana. Y no fue suficiente.

En la segunda parte de su "Discurso", Beristáin se dirige a los "hijos de españoles", dejando a un lado ya a los "infelices vasallos del bárbaro Moctezuma" (es decir, a los indios). A los criollos, España les dio la sangre, la vida, la honra, la hacienda de que disfrutan, y agrega: "¿Quién levantó esa casa en que vivís, quién os traxo y enseñó esa ciencia con que brilláis?... Un español hijo de España, vuestra madre' (p. 15).

Después se dirige a los descendientes de los conquistadores, abriendo de nuevo una herida jamás cerrada al decirles que sus antepasados "no conquistaron este reyno para sí, sino para España [...] Disfrutad en buena hora vuestras posesiones y rentas, pero jamás olvidéis que España os dio y os ha conservado intacto ese mayorazgo que gozáis" (pp. 14-15). El problema, aunque lejano en el tiempo, seguía estando vivo para muchos criollos descendientes de conquistadores. Porque desde luego, el sistema feudal que éstos defendieron con su conquista fue arrasado por la monarquía, que procuró por todos los medios (incluido el de la intervención inquisitorial ${ }^{43}$ que los descendientes de los conquistadores no monopolizaran demasiadas parcelas de poder económico, o grandes extensiones de terreno, o minas productivas. El papel de los conquistadores después de su lucha fue empequenecido por los reyes españoles, que temieron que se creara en América una nobleza feudal incontrolable, por la distancia que los separaba de la corte. Los reyes consiguieron que los antiguos conquistadores se integraran en la administración, pero no les concedieron poder en ella. Este hecho lo conocían sus descendientes y de ello, probablemente, se lamentaban.

Para Beristáin "no hai otra diferencia entre nosotros [se refiere a los blancos de Nueva España], sino que unos venimos ayer a la América y otros han llegado hoi. Por lo demás esta tierra tiene dueño y lo es sin duda la nación española" (p. 16).

La tercera parte del sermón tiene por objeto, una vez asenta-

43 Recuérdese el sonado caso de Martín Cortés, que defendía unas ideas de vasallaje (y herencia feudal) ya obsoletas en el momento, lo que le costó un proceso inquisitorial. 
do el vasallaje de todos los habitantes del reino, resaltar los favores que los mexicanos reciben de España. Para ello, el orador personaliza y muestra su propio caso como ejemplo. Es un método curioso, nada frecuente en este tipo de literatura, porque si bien es cierto que con frecuencia se exponían uno o varios ejemplos que sirvieran para probar las tesis que se defendían, no lo es menos que éstos raramente se basaban en las experiencias personales del predicador.

Beristáin se atrevió a ponerse a sí mismo como ejemplo de sus afirmaciones, desafiando las críticas que habitualmente recibía por sus intervenciones en el púlpito:

Dexadme, dexadme que me desahogue y que os diga cosás que [a]caso no habéis oído y que os han de agradar... Los reyes y los príncipes admiten bemignos en su augusta presencia [...] a cualquier americano..., los ministros primeros y segundos y los grandes [...] nos admiten en sus casas, a sus mesas y a sus tertulias sólo a título de americanos [...] y los pueblos todos [...] nos obsequian y nos prefieren aun a sus naturales (pp. 22-23).

Sigue la lista de los que han gozado de esta preferencia, con los nombres de los americanos que han triunfado en la península: Portillo en Valencia y él mismo, que fue "adoptado" por el obispo Francisco Fabián y Fuero; Olavide en Sevilla y el jalisciense Ceballos; Alcalá con el peruano Bodega. Y, como la lista se le acaba muy pronto, Beristáin termina su argumento hablando de inmediato de su experiencia vallisoletana en un ejercicio que podía ser interpretado como de pedantería:

Valladolid, corte antigua de nuestros reyes, ¿qué viste en mí, el más pobre y despreciable de los americanos, para exaltarme tanto y de tantas maneras y preferirme a treinta doctores castellanos a la primera oposición, y a los tres días de incorporado a tu gremio, para una cátedra de Teología? Y tú, Vitoria, primera ciudad de las Bascongadas ¿por qué, di, me elegiste con agravio de tus hijos beneméritos para la canongía lectoral de tu iglesia? ¿Por qué? Sólo porque yo era americano y no más (pp. 24-25).

El orador remata su argumento afirmando que todos los americanos que van a España consiguen lo que quieren, y si hay alguna excepción, es por culpa del americano. Afirma que los empleos, aun en España, se conceden de preferencia a los americanos y no a los españoles y, finalmente, que la Junta Central 
que en el momento rige los destinos de la Madre Patria llama "hermanos" a los americanos, con lo que no se puede pedir más.

Sobre la falacia de los dos primeros argumentos creo que ya hemos insistido bastante, pero sobre el último punto no está mal recapacitar. En las sesiones inaugurales de las Cortes de Cádiz que se llevaron a cabo desde el 24 de septiembre de 1810, los americanos estuvieron en franca minoría frente a los españoles, a pesar de que representaban a poblaciones cuyo número superaba varias veces las de la península: en representación de América había 53 hombres, mientras por España había 150 delegados. Nada se obtuvo, a pesar de las intervenciones de los delegados americanos. Éstos eran más radicales que los españoles y trataron de defender las aspiraciones de sus pueblos, los derechos de los negros, indios y castas; pidieron la supresión de las alcabalas y la libertad de comercio (de que sólo gozaban México y Venezuela). Pero sus intervenciones cayeron en el vacío, ante el temor de los españoles de contribuir (si concedían estas peticiones) a la independencia de América ${ }^{44}$. Los delegados americanos, en franca minoría, volvieron a sus colonias llenos de frustración y con el convencimiento de que no había otro remedio que cortar con la metrópoli. Habían pedido también la igualdad de representación para los delegados de ambos lados del Atlántico, pero esta moción tampoco progresó, porque de haberlo hecho, los delegados americanos hubieran triplicado el número de los españoles. También fracasó la petición de que se diera acceso equitativo a todos en la provisión de empleos. Así, vemos que los mismos puntos que Beristáin daba como realidades efectivas, un año después de predicado su sermón se planteaban en Cádiz como reivindicaciones que no podían ser aceptadas. Las pocas modificaciones que se concedieron llegaron demasiado tarde, cuando la revolución de independencia las convertía en papel mojado, cuando la insurgencia se hallaba ya triunfante en la mayor parte del territorio novohispano e iberoamericano, y nunca llegaron a ponerse en práctica ${ }^{45}$.

Beristáin concluye su sermón recapitulando todo lo expuesto anteriormente y exhortando a los mexicanos a seguir fieles a Es-

${ }^{44}$ Luis Villoro, art. cit., p. 338.

${ }^{45}$ Para mayor información sobre la actividad de los delegados, véase Elsa Gracida y Esperanza FujIYaki, "La revolución de Independencia", en México, un pueblo en su historia, UAP, México, 1983, pp. 35-40, esp. pp. 11-87. 
paña y a no separarse de ella jamás. El orador maldijo a quienes no deseaban seguir siendo los

hombres más felices del globo. Maldito sea de Dios y de sus ángeles, y merezca nuestras imprecaciones más terribles cualquiera que se atreva a alucinarnos con sistemas nuevos y locas esperanzas de mejor fortuna en ellos. No, Dios mío, no permitas que lleguen a nosotros ni los pestilentes vapores que despide [h]acia todas partes aquella hidra monstruosa que quiere tragarse los tronos de tus ungidos y aun tu mismo solio eternal (pp. 31-32).

Como sabemos, estas exhortaciones no fueron escuchadas.

"Oración panegírico-eucarística" (1809)46. El día de la Inmaculada Concepción, los caballeros de la Real Orden de Carlos III en la capital de la colonia, organizaron una acción de gracias por la construcción, en España, de la Suprema Junta Central que velaría por los intereses de la corona frente a la invasión francesa y a la ausencia de mando real. La noticia, como era normal, llegaba a la colonia con unos meses de retraso, pues la Junta se había establecido el 25 de septiembre y en las Indias no se tuvo noticia de ello hasta el 29 de noviembre.

Tanto el gobierno virreinal, presidido por Garibay, como el eclesiástico, por Lizana y Beaumont, estuvieron de acuerdo en respaldar la iniciativa de los caballeros de la Orden. El predicador escogido fue Beristáin, que era uno de sus miembros y que estaba especializado, casi podríamos decir, en este tipo de sermones.

La sesión fue muy solemne, pues tomaban parte en ella los estamentos más importantes de la corte virreinal, de la administración y del alto clero catedralicio; los conventos, algunas comunidades indígenas de los alrededores, el clero secular y el cabildo eclesiástico, y los caballeros de Carlos III, grupo formado por la élite de la clase dominante en la Colonia. La relación de los participantes es demasiado larga para detallarla aquí ${ }^{47}$, pero el propósito de tal acto, como el de la posterior publicación de la "oración" y la descripción de la ceremonia, se hizo para que

46 "Oración panegírico-eucarística pronunciada en esta festividad por..." en el volumen Solemne acción de gracias que tributaron al Todopoderoso en la Metropolitana de México, los caballeros de la Real y distinguida orden de Carlos III, Impta. de Fernández de Jáuregui, México, 1809.

47 Tbidi, pp. 28-32. 
"siempre haya constancia en ella de los fieles y nobles sentimientos de religión, vasallage y patriotismo de que están poseídos los caballeros residentes en la fidelísima y muy leal capital de Nueva España"' (p. 33).

En el exordio Beristáin echa mano del viejo tópico de la falta de méritos del orador para abordar un asunto que requiere más luces que las suyas, dado su grandioso objeto, que no es otro que el de cantar las glorias de la nación española y la fidelidad eterna de la colonia a su Madre Patria. Se trata de un recurso frecuente en todo tipo de discursos retóricos, y en él basa Beristáin esta primera parte introductoria de su sermón. Se trata también de ensalzar a la Virgen que se conmemora ese día, la Inmaculada Concepción, patrona de la orden de Carlos III, y de dar gracias por la instauración de la Junta Central de Aranjuez. Todo ello con el fin de conseguir el pronto regreso a España del "idolatrado, tanto corno perseguido Fernando" (p. 41).

Para emprender tan complicado discurso, Beristáin se encomienda a la Virgen y agradece (en nota) a varios personajes, los favores que le hicieron a lo largo de su vida para poder expresar sus sentimientos de agradecimiento. Entre los personajes que cita está Floridablanca, a quien dice deberle la cátedra de Valladolid y el apoyo a su gestión como fundador de la Sociedad Económica de Amigos del País, el permiso de investigación de varios documentos escurialenses, la beca concedida para viajar por Europa y el permiso de editar el Diario Pinciano.

Cita también a Jovellanos, al marqués de Castel-Rodrigo, al vizconde de Quintanilla y a otras personas que lo ayudaron en España. Aunque evidentemente esta nota no entró en el discurso oral y fue agregado a la hora de publicación del impreso, no deja de ser curiosa la afición que tenía Beristáin a echar flores en su propio huerto. Se trata de una particularidad del poblano, que traduce tal vez un excesivo aprecio por su persona; constituye una interesante pista sobre el carácter narcisista de Beristáin.

La “'Oración"' está precedida por unos versículos de Lc. 1, 68-69: Benedictas Dominus Deus Israel, quia visitavit et fecit redemptiones plebis suae: et erexit cornu salutis nobis in domo David pueri sui (Bendito es el Señor Dios de Israel, porque visitó y redimió a su pueblo y porque erigió en la casa de su siervo David la fortaleza de nuestra salud).

Lo que sigue es una interpretación complicada y barroca de los temas de la festividad de la Asunción y de la creación de la Junta Central, anunciados en el exordio. Con ellos compone una 
extraña ensalada en la que Beristáin compara a David con Fernando, a Napoleón con el diablo y a la Virgen con España. Para él, el fragmento de San Lucas habla de la resurrección en la casa de la madre e interpreta que María redime al pueblo español del yugo francés, fomentando en la casa de David (Fernando) la gloria imperecedera. María es la patrona de España, que es "su ca" sa, silla, trono y torre de David"' (p. 45). La Virgen ha hecho posible la creación de la Junta Central para proteger los derechos "del joven David Fernando VII".

No hace falta decir aquí que el celo españolista y la pasión política estaban llevando al erudito poblano al borde del delirio. Con estas comparaciones transgredía las directrices que en contra de esta práctica habían hecho fray Luis de Granada, Gregorio Mayáns y Sánchez Valverde entre otros muchos, que rechazaban la comparación de los personajes de la realeza o de los héroes con personajes bíblicos.

Beristáin hace caso omiso de estas reiteradas recomendaciones para resaltar el carácter semi-divino del heredero del trono español. En unos momentos en que ya muy pocos creían en la filiación divina de las cabezas reinantes (algunas de las cuales habían rodado hacía tiempo), apostar por esta teoría era de nuevo un anacronismo.

El rey, según el orador poblano, es el representante de Dios entre los pueblos. María es comparada con España. Por un lado, madre de Cristo (representado por Fernando), por otro, madre de españoles y americanos. España y María son inmaculadas y puras, y se han visto colmadas con los mejores dones de Dios. María es la peor enemiga de Satanás, como España lo es de Napoleón, su encarnación en la tierra. María encontró su mejor morada entre los españoles, como lo demuestran sus apariciones en Zaragoza, donde desde su trono del Pilar vela por España desde hace 18 siglos (?). El enemigo de España-María es NapoleónSatanás. La descripción que nos hace Beristáin de este hombre bien vale una cita, aunque sea prolongada:

[Napoleón es] un hombre oscuro, de baja ralea, que alimentado y educado con el veneno y máximas de los filósofos materialistas, agotó también toda la ponzoña de Maquiavelo; digno ministro de los abominables y sacrílegos regicidas de Francia $[\ldots]^{48}$. Jacobino en París, mahometano en Egipto y católico en Roma, sojuzgó

${ }^{48} \mathrm{El}$ atentar contra la vida de un rey era considerado herejía. 
a los franceses, engañó a los musulmanes y se burló de la Silla de San Pedro: siempre ambicioso y siempre pérfido, osó ocupar el solio de Clodoveo, de Carlomagno, de Luis el Santo; destronó a los soberanos de Italia, destruyó las repúblicas libres de Venecia, Génova y Holanda, cortó las alas a las águilas caudales de Alemania y Prusia, animó al Turco contra los príncipes cristianos y pervirtió al honrado zar de Moscovia (pp. 51-52).

Beristáin continúa su narración con la invasión de Portugal y los engaños que permitieron que Carlos IV saliera de España y que, a cambio, entraran en ella 200,000 franceses. Todo para dar el reino a un hermano del tirano corso, que se había adueñado de Fernando VIL

$\mathrm{Ni}$ una palabra sobre Grodoy, ni sobre las sucesivas renuncias de los protagonistas a la corona española, ni sobre los complots de Fernando contra Carlos y de Carlos contra Fernando, que los habían puesto en las manos de Napoleón.

Beristáin ve a Carlos y Fernando como dos seres inocentes e ingenuos que cayeron en las garras de Satanás-Napoleón por un exceso de bondad. Como éste temía a los españoles - dice nuestro predicador-, tuvo que recurrir al "dolo y a la perfidia" para conseguir España, cuando a los otros países los había sojuzgado con su espada. Napoleón sabía, dice Beristáin, que los españoles eran, entre todos los pueblos de la tierra, "como los leones entre todas las fieras del campo"' (p. 55).

Pero la Virgen María no permitió que Napoleón se saliera con la suya, pues como había sucedido en las batallas de las $\mathrm{Na-}$ vas o de Covadonga, en las victorias de Zaragoza, Valencia o Bailén, María mostró su favor a los españoles. La Virgen les concedió la "protección visible del cielo" (p. 58).

En la segunda parte, el predicador se lamenta de la pérdida de David-Fernando, "nuestro rey adorado", pero

las juntas erigidas en diversas provincias fueron sus sustitutas y aun sin cabeza, sin príncipe, la nación encontró quien la dirigiese y la alentase bajo la dirección de nuevos cicerones como Moñimo, Saavedra, Jovellanos; nuevos Demóstenes que han escrito contra el tirano y gran número de españoles y americanos que han luchado contra él y con sus haciendas y su vida han defendido a la patria.

Pero aun uniendo todos los esfuerzos, una nación necesita un jefe 
y ese jefe, en ausencia de Fernando, es -evidentemente- la Virgen María, que ha erigido a la Junta Central de Aranjuez para que una los derechos dinásticos de Fernando con los derechos de sus súbditos, salvaguardando el puesto transitoriamente vacante del rey. Ella "vela por el orden y la justicia, la salud y la defensa" de España (p. 64).

Con la protección de María, Napoleón será derrotado en toda la línea y volverá el "dulce" Fernando, nieto de Carlos III, quien puso a los pies de la Virgen todo su imperio. Beristáin termina esta extravagante "Oración" pidiendo a María que ruegue a la Trinidad "por la completa redención política de España y por la total confusión de sus enemigos", para que "Fernando reine en su trono" a la mayor brevedad.

El "Discurso para el Domingo de Ramos" (1815), también editado como "Discurso cristiano declamatorio contra los rebeldes de la Nueva España", $(1816)^{49}$. El 19 de marzo de 1815, cuando Beristáin pronunciaba este "Discurso" sufrió un "accidente imprevisto" (en realidad una embolia), que lo postró en la cama hasta su muerte, que ocurrió unos meses después. Naturalmente, el incidente fue aprovechado por los insurgentes para sugerir que Dios estaba de su lado, pues había castigado a su temible enemigo de manera tan ostensible, cuando se hallaba maldiciendo al caudillo Hidalgo.

Los realistas, por su parte, dieron el "Discurso" a la imprenta, acompañándolo con una "Nota" que vamos a transcribir por su gran interés:

Un accidente imprevisto que atacó la salud del sabio y patriota autor de este Discurso Dr. D. José Mariano Beristáin, en el acto de pronunciarlo, impidió su conclusión con general sentimiento de todos los buenos, no sólo por haberse visto privados de gozar del resto de la cristiana, elocuente y patriótica oración, sino por la indisposición del benemérito orador a quien aman y veneran cuantos no están inoculados con el veneno insurreccional. La impiedad y la blasfemia osaron profanar el santo nombre de Dios y atribuir a su divina justicia la enfermedad del fervoroso Deán, porque se atrevió (dicen) a insultar al corifeo de la insurrección, Hidalgo. ¡Último y execrable desbarro de estos sacrílegos, querer que la rectitud infinita se interese por el crimen, la maldad y la irreligión!

49 La primera edición es la de la Impta. de Benavente, México, s.a. (pero de 1815); la segunda está publicada por la Impta. de Álvarez en Madrid, 1816. 
Los católicos se han escandalizado de tal desenfreno, y han visto en esta opinión descarriada la última ceguedad de los rebeldes, y el verdadero castigo de la Providencia sobre ellos, pues los ha abandonado a su flaqueza y mal consejo.

Para los hombres sensatos es inútil la refutación de tan abominable delirio, y para los ilusos, estéril y vana, porque trastornado su juicio carecen hasta de remordimientos, que es la más cierta señal de proscripción. Así que complaciéndonos en seguir las huellas del sabio Dcán, constante y acérrimo defensor de la justa causa española antes y después de la rebelión, y esperando por ello la protección del cielo antes que su ira y su castigo, nos contentamos con tributarle este corto obsequio de nuestra amistad y gratitud, satisfaciendo al mismo tiempo los deseos de tantos buenos patriotas que anhelan por tener y conservar esta preciosa producción.

Entretanto, dexemos a los insurgentes que blasfemen y rabien cuanto quieran. No es nuevo en ellos el encono contra los hombres de bien y particularmente contra el benemérito americano autor de la oración, porque con la palabra, con la pluma y con las obras ha sido siempre su principal y mayor antagonista. En recompensa, cuenta con el amor de todos los españoles buenos de ambos mundos que le veneran no sólo como un digno eclesiástico y un erudito de primer orden, y tranquilo con el puro testimonio de su conciencia, sigue con sosiego la senda de la razón y la verdad y compadece con cristiana caridad los extravíos de sus ciegos compatriotas $^{50}$.

Partes del sermón. El breve exordio (que corresponde a un muy breve sermón) es de orden narrativo y sugiere que la infidelidad y la traición que ahora intentan los mexicanos con España ya fueron vividas por Jesucristo "aclamado hoy por el pueblo [como] rey de Jerusalén, hijo de David y enviado de Dios y [...] blasfemado, dentro de cinco días por ese pueblo, condenado a muerte e ignominiosamente crucificado"' ( $3^{\text {a }}$ hoja sin numerar).

Luego, el sermón propiamente dicho se divide en tres partes muy cortas: en la primera, Beristáin habla de la terrible experiencia vivida por Jesucristo a causa de esa traición. Dice Beristáin que era lógico que el pueblo hebreo se sintiera jubiloso por la presencia de su salvador, y también que los fariseos traidores y los escribas soberbios lo rechazaran. Lo que ya le parece extraño es que ese mismo pueblo hebreo, "esos mismos sean los que dentro de cinco días corten espinas para coronarle y cañas para escarnecerle; le desnuden de sus vestidos, pidan su muerte y gri-

50 También la reproduce Agustín Millares Carlo, op. cit., pp. 78-79. 
ten que no tienen ni conocen más rey que el gentil romano", (p. 3).

Los dicterios contra la mudable Jerusalén son, como siempre, abundantes: le reprocha su "vil inconstancia" y su "abominable perfidia" y le pregunta: "¿Qué motivo pudo darte ese justo y beneficientísimo hombre para tan execrable infidelidad?"' (p. 4).

Beristáin anuncia que no se debe condenar sólo al pueblo de Jerusalén, sino más bien a quienes lo incitaron: los escribas, fariseos y "los sacerdotes y doctores de Moysés fueron los seductores y pervertidores del pueblo" (p. 5). Para fundamentar estas afirmaciones, Beristáin recurre a la autoridad de los cuatro evangelistas, a quienes cita en los fragmentos correspondientes. Con estas razones no exculpa al pueblo, sino que señala a los verdaderos culpables de su "extravío". Y una vez puesto el pretexto, pasa, en la segunda parte, a reflejar estas ideas en su momento histórico:

Mas esperad, suspended por un momento la sentencia y el castigo y trasladémonos a otras plazas y calles más inmediatas que las de Jerusalén [...] ¡Oh días de placer dulce [...] días en que el pueblo mexicano aclamó por su rey al mocente, al justo, al pacífico, al perseguido Fernando VII! [...] La paz, la concordia, la amistad verdadera reynaron en nuestros corazones (p. 7).

Y el torrente de los felices recuerdos de esos días llena las (breves) páginas del discurso del poblano que se extasía rememorando los gritos con que se juró fidelidad al "justo e inocente' rey:

¡Viva Fernando nuestro rey, viva la España valerosa; viva la América fiel; viva salvo el hijo de los reyes católicos descubridores de la América: Hosanna filio David. Viva salvo el hijo de los Felipes, de los Fernandos y de los Carlos, a quienes México y la América española deben su religión, sus templos, sus monasterios, sus academias, su población, su grandeza y su felicidad! (p. 8).

Una vez recordados con emoción y multitud de exclamaciones los días en que se veneraba el nombre de Fernando, Beristáin pasa al verdadero tema del sermón, que es el ataque frontal contra los insurgentes, en la tercera y última parte de este breve "Discurso".

Beristáin no se explica — según dice- el cambio experimen- 
tado por el pueblo de México, que en julio de 1808 había aclamado al hijo de Carlos IV y luego de "cuatro días" aclamaba ya a los insurgentes y se pregunta “ ¿Cómo pudo convertirse aquel aplauso en execración [...] nuestro amor a Fernando en el odio más sacrílego [...] Los vítores y vivas en blasfemias y maldiciones [...] Nuestra paz envidiable en guerra bárbara y sangrienta? [...] ¿Cómo ha sido? Lo diré: Nuestros escribas y fariseos, los aprendices de políticos y de filósofos ilustrados, seduxeron, pervirtieron a los pueblos' y, en seguida, Beristáin pronunció las fatales últimas palabras que se le oyeron decir en un púlpito: "No debe reconocerse a Fernando por rey, sino al apóstata Hidalgo, al Judas de la Nueva España, al Barrabás de la América: Non hunc sed Barabbam" (pp. 9-10). En este momento, según parece, Beristáin sufrió el ataque que le llevó a la tumba.

Sin embargo, el impreso está completo, seguramente a partir del manuscrito que elaboró Beristáin, aunque su brevedad desacostumbrada nos hace sospechar que éste pulía y aumentaba considerablemente sus piezas orales hasta dejarlas listas para la imprenta. En este caso no sucedió así.

Beristáin escribía más adelante:

Concluyamos pues que así como el pueblo hebreo aclamó a Jesús por su rey y salvador cuando le dexaron en libertad los escribas y fariseos, el pueblo americano reconoció y aclamó por su rey legítimo a Fernando VII cuando estuvo libre de la maldición de los malvados. Que tanto el uno como el otro sólo engañado y seducido pudo haberse conjurado contra su príncipe: finalmente que los escribas, fariseos, doctores y sacerdotes apóstatas de uno y otro pueblo son reos de maldición eterna por enemigos de Dios, de su rey y de su patria (pp. 11-12).

Podríamos decir que aquí Beristáin escribe sobre "la triple infidelidad castigada".

Los dicterios y las maldiciones siguen su curso en este sermón:

Sí, malvados, esta es la sentencia que ha dado contra vosotros el leal y fidelísimo auditorio que me escuchaba. Sí, traidores: nosotros amamos esta dulce patria nuestra y vosotros la aborrecéis [...] Vosotros habéis preferido a estos sólidos y verdaderos bienes las ideas fantásticas y criminales de una independencia funesta, de un mando usurpado [...] Hijos viboreznos de la infeliz América, vo- 
sotros habéis roto sus entrañas por apresuraros a salir del seno que os abrigaba... Políticos torpes [...] ¿a qué aspiráis? (pp. 12-13).

$\mathrm{Y}$ volviendo al auditorio, les pregunta si prefieren a Jesús o a Barrabás: a Fernando "vuestro padre y monarca augusto" o a los insurgentes "ladrones y asesinos" (p. 13).

Termina el sermón hablando de consuelo "porque después de la conjuración de estos judíos, de las burlas, azotes y curcifixión de su rey, vendrá sobre ellos toda la ignominia y castigo de la ingrata Jerusalén; y para vosotros la resurrección, la felicidad y la gloria' (p. 14).

Tal vez muchas veces se predicó en el púlpito contra los insurgentes, pero dudo que nadie se hubiera atrevido a comparar a Fernando VII con Jesucristo. El sermón de Beristáin rebosa odio.

El comentario de un contemporáneo. En uno de los ejemplares de la Biblioteca Nacional de México, encontramos un breve comentario sobre el sermón, que fue escrito en las últimas dos páginas blancas del impreso. Es interesante su transcripción:

Sermón célebre del canónigo Beristáin. Este sermón es parto digno de la genial y baja adulación del canónigo Beristáin, se predicó tal qual se ha impreso por que hacía gala de parecer bajo, ruin y exaltado en el concepto de los gachupines. Al llegar al pasage del folio $1^{\circ}$ que está marcado con este carácter \# le atacó el insulto, comenzó a balbutir, y ya no volvió a profanar más la cátedra de la Verdad.

Es de todo punto falso que los Insurgentes prescribiesen con pena la muerte a los labradores si pagaban diezmo a los colectores y ellos lo que hicieron fue aplicarlo para hacer la guerra a los españoles, así como éstos nos la hacían con los mismos.

La pobreza en el culto de la catedral de México en la Semana Santa del año 1815 no dimanó de este principio sino de que Beristáin gastó más de 24 mil pesos de la iglesia en celebrar el regreso de Fernando $7^{\circ}$ a España.

El pestilente vicio de la adulación aún hoy domina en el púlpito bajo el sistema republicano. Un predicador yorquino ha osado comparar a Poinset, al inicuo Poinset, fundador del rito de York con Moysés, y al negro Guerrero ${ }^{51}$ con el ángel tutelar de la Amé-

51 Vicente Guerrero contribuyó ostensiblemente a la independencia hasta el "abrazo de Acatempan", cuando cedió el mando y reconoció como superior a Agustín de lturbide. Tal vez el ejemplar del sermón y la anotación que transcribo hayan pertenecido a Carlos María de Bustamante, pero no puedo asegurarlo. 
rica... acaso Dios castigará semejante bajeza del mismo modo exemplar que castigó la de Beristáin.

Además de su valor relativo como testimonio de lo que algunos pensaban sobre la oratoria de Beristáin, nos podemos percatar que la oratoria sagrada después de la República, siguió por los mismos caminos que había marcado Beristáin con los sermones que aquí hemos comentado.

Gabriela Zayas de Lille Universitat de Barcelona 